\title{
Heart rate of Mangalarga Marchador mares under marcha test and supplemented with chrome $^{1}$
}

\section{Raquel Cheyne Prates ${ }^{2}$, Heloisa Helena Capuano de Rezende ${ }^{2}$, Ângela Maria Quintão Lana ${ }^{3}$, Iran Borges ${ }^{3}$, Patricia Carneiro Bernardes Moss ${ }^{4}$, Raquel Silva de Moura ${ }^{2}$, Adalgiza Souza Carneiro de Rezende ${ }^{3}$}

\author{
1 Pesquisa financiada pela Fapemig, com apoio da CAPES e do CNPq. \\ 2 Programa de Pós-graduação em Produção Animal/Escola de Veterinária/UFMG. \\ ${ }^{3}$ Departamento de Zootecnia/Escola de Veterinária/UFMG. \\ ${ }^{4}$ Curso de graduação em Medicina Veterinária/Escola de Veterinária/UFMG. Bolsista de Iniciação Científica da Fapemig
}

\begin{abstract}
The objective of this experiment was to characterize the heart rate (HR) of twelve Mangalarga Marchador mares, before, during, and immediately after 5, 10, 15 and 20 minutes of marcha tests, evaluating the effect of chrome on cardiac performance. The mares were assigned into three groups distinguished by supplementation of 0,5 and $10 \mathrm{mg}$ of $\mathrm{Cr}$, respectively. The experiment was conducted in two phases, 24 and 6 days, respectively. The first phase included diet, $\mathrm{Cr}$ and exercise adaptation and the second, three 50-minute marcha tests, every other day. Before the tests, a Heart Rate Monitor was adapted to check the HR. The assay was randomly conducted in split-splot arrangement, with four replications. Mean comparisons were performed through minimal significative difference (MSD) test and the time evaluation was performed through regression adjustment model. The results showed positive effect of Cr on heart rate performance and animal return. Chrome did not influence the heart rate during the marcha tests and the HR values characterized the marcha tests as sub maximal intensity exercise.
\end{abstract}

Key Words: equine, frequency meter, marcha tests, mineral

\section{Freqüência cardíaca de éguas Mangalarga Marchador submetidas a provas de marcha e a suplementação com cromo}

RESUMO - Objetivou-se caracterizar a freqüência cardíaca de 12 éguas Mangalarga Marchador antes, durante, imediatamente após as provas de marcha e aos 5, 10, 15 e 20 minutos após as provas e identificar os efeitos do cromo sobre o desempenho cardíaco desses animais. As éguas foram distribuídas aleatoriamente em grupos diferenciados pelo fornecimento de 0 , 5 e $10 \mathrm{mg}$ de cromo (Cr). O experimento foi dividido em duas etapas, a primeira (24 dias) para adaptação à dieta, ao cromo e ao exercício; e a segunda (seis dias), para as provas de marcha, realizadas em dias alternados, totalizando três provas de 50 minutos. A freqüência cardíaca foi observada utilizando-se um monitor de freqüência cardíaca Polar. O delineamento experimental foi inteiramente ao acaso com arranjo em parcelas subsubdivididas. A comparação das médias foi feita por DMS (diferença mínima significativa) e, para avaliar o efeito de tempos de avaliação, ajustou-se um modelo de regressão. Os resultados comprovaram que o cromo melhorou o desempenho cardíaco, influenciou positivamente na recuperação dos animais e não afetou a freqüência cardíaca durante a prova de marcha. Os valores de freqüência cardíaca encontrados caracterizaram a prova de marcha como exercício de intensidade submáxima.

Palavras-chave: concurso de marcha, eqüinos, freqüencímetro, mineral

\section{Introduction}

According to study conducted at the Luiz de Queiroz Agriculture School (Guerra \& Medeiros, 2007) Brazil possesses the third world largest equine stock and more than one million people are involved in activities related to horse husbandry. This branch of farming responsible for 3.2 million direct and indirect jobs and a movement of
322 million US dollars/year in the compound of the Brazilian agribusiness.

The Mangalarga Marchador breed is the most numerous national equine breed and it has been submitted to heavy exercises (marcha tests and endurance races), long distance transport (cavalcades) and every type of stress related to competitions. Few works have been accomplished with this breed, which have been focused 
on marcha and are submitted to exhausting tests, without similar in the world (Rezende, 2006).

Chrome (Cr) was recognized as essential nutrient for humans and, for animals, it can be involved in some physiologic processes, what was showed in the energy metabolism response to exercise in Thoroughbred horses (Pagan et al., 1995). Lehninger et al. (1995) reported that due to its role as factor of glucose tolerance, Cr supplementation reduces the serum insulin levels for being involved in the carbohidrates, proteins and lipids metabolism. Furthermore, Mowat et al. (1993) demonstrated, in bovine, its importance in stress control.

The evaluation of the performance of several physiological systems in relation to stress caused by some physical activity has allowed the development of the exercise physiology in humans and animals. Also, the observation of physiological adaptations to the systematic exercise is an important tool in evaluating the sportive performance of athlete horse (Baldissera, 1997). The heart rate influences physiologic alterations that occurs before and after the exercise and the speed of its return depends on the exercise intensity and duration, the animal conditioning and the environmental conditions (Weigle et al., 2000).

According to Rezende (2006), the marcha contest is an equestrian test without similar in the world, which can be defined as a long-duration exercise with great energy expense, in which the animal develops, in circle, a long course without rest and in constant and excessive speed.

There are few reports in literature related to Mangalarga Marchador equine preparation for participation in marcha tests and to the effects of $\mathrm{Cr}$ on the performance of athletic horses. In addition, great part of the supplements aimed at equines has its formulation based on researches accomplished with other species or even human athletes. Therefore, this work was aimed to characterize the heart rate of Mangalarga Marchador mares in marcha tests and to identify possible benefits of the use of $\mathrm{Cr}$ on the heart performance of these animals.

\section{Material and Methods}

This experiment was conducted in the period from January to February 2005. Twelve Mangalarga Marchador mares with age between 6 and 8 years and weight ranging from 361 to $436 \mathrm{~kg}$ were used. The mares were randombly assingned into three groups (T1, T2 and T3), four horses per group, differentiated by the administration of $0,5 \mathrm{mg}$ and $10 \mathrm{mg}$ of $\mathrm{Cr}$ (Quelated Chrome by Zimpro), respectively. The distribution of the animals in the experimental groups was based on the following criterion: each two mares with similar weight, age and heart rate (HR), the closest as possible, were assigned one for each Cr supplementation.

The animals were grazing in a Coast Cross (Cynodon dactylon x Cynodon nlemfluensis) paddock, with drinking fountain and covered hod for water and mineral salt ad libidum, respectively. The concentrate was offered at 6:00 am and 1:00 pm in service units. The mares have their weight weekly checked in the beginning of the preexperiment. At each weighting time, 2,5\% of the body weight was calculated and $40 \%$ of the obtained body weight value represented the amount of concentrate that would be daily offered to the animal, until the next weighting time (NRC, 1989).

The experiment lasted 30 days and it was divided into two phases, 24 and 6 days, respectively. The first phase (pre-experimental) was for adaptation of the animals to the diet and to the exercise they would be submitted in the second phase. In the pre-experiment, the conditioning of the animals to the work was daily performed, ten minutes walking, five marching, four galloping, five marching and again ten minutes walking, according with adaptations to the recommendations of Meirelles (1997). Every other day, HR was controlled and when it was equal or below 52 beats per minute (bpm), it indicated that no representative effort was performed for the conditioning and the exercise was increased in ten minutes on time of marcha.

When the beats were between 63 and 71 per minute, it demonstrated that the animal presented good return and the exercise was maintained. When HR was above or equal to $72 \mathrm{bpm}$, it indicated excess of work and the time of marcha was reduced in the proportion of five minutes a day untill beats were between 63 and $71 \mathrm{bpm}$.

In the experimental period, the animals were submitted to three marcha proofs accomplished in alternate days, according to the XXIII Mangalarga Marchador National Exhibition regulations, accomplished by ABCCMM(2004). In these tests, the mares were maintained in cadenced marcha for 50 minutes, 25 minutes in the clockwise direction and 25 in the counterclockwise direction, with medium speed of $12 \mathrm{~km} /$ hour.

Room temperature and air relative humidity were measured with a digital thermometer and daily recorded during the entire experimental period in order to obtain data to evaluate the animals' performance in the registered temperatures and to verify if the $\mathrm{Cr}$ would affect the performances under these conditions. 
Heart rate was measured at the test days using a frequencimeter that was adapted to an elastic strip surrounding the thorax of the animal, so that the device was close to axilla. This HR monitor allowed its reception in the clock that was in the horseman pulse or attached to the saddle. After the test, the heart beats were transmitted from the clock Polar6 to a notebook through an infrared device. The "Polar Precision Performance" program installed at the computer made possible the HR reception before, during, soon after and 5, 10, 15 and 20 minutes after the test.

The experimental design was fully random with arrangement in sub-subdivided parcels, with $\mathrm{Cr}$ doses as parcels, the days of tests as sub-parcels and the time of evaluation as sub-sub-parcels, for the groups that received 0,5 and $10 \mathrm{mg}$ of $\mathrm{Cr}$, with four replications. The comparison means of the experimental groups was performed through MSD to evaluate the effect of the evaluation time on the HR, a regression model was adjusted. Lilliefors tests for normality and Bartlet for variances homocedasticty was conducted.

\section{Results and Discussion}

Before the test on the first day (Table 1), HR was higher in all groups in relation to the second day. This may be due to the stress of the animals on the first day of test and the presence of the personnel involved with the adjustment of the frequencimeter to the animals. A reduction of HR before the test in all groups $(\mathrm{P}<0.05)$ in the second day was also observed, what demonstrates the adaptation of the animals to the routine they were submitted before the tests. However, the use of $\mathrm{Cr}$ did not influence the HR values. These results are similar to those observed by Thomas et al. (1983), who verified that, in rest, HR does not differ after training. Similarly, Evans (1994) affirmed that, in the equine at rest, HR does not usually decrease with training, as observed for human beings. According to this author, the use of HR measures to monitor the physical conditioning is restricted to measures before and after the exercise and the HR of horses in rest depends, mainly, on the degree of the individual relaxation.

The HR values observed before the test in the first day are in agreement with Evans (1994), who reported that HR can increase quickly for more than $100 \mathrm{bpm}$ if excitement in anticipation to exercise occurs. In agreement with this author, the fast changes between 20 and $110 \mathrm{bpm}$ in HR in rest can be explained entirely by alterations in the simpathetic nervous activity.

Still after the test, the group that did not receive $\mathrm{Cr}$ (control group) showed larger HR in the first and second day in relation to the group that received $5 \mathrm{mg}$ of $\mathrm{Cr}(\mathrm{P}<0.05)$. However, although these animals have shown better results in relation to the control group in the first two days, on the third day, they presented HR as high as the animals that did not receive $\mathrm{Cr}(\mathrm{P}>0.05)$. However, the group that received $10 \mathrm{mg}$ presented unaffected HR in the three test days $(\mathrm{P}<0.05)$, which demonstrates positive effect of $\mathrm{Cr}$ on the performance of these animals.

On the second day before the test, the HR of animals, especially of those who received 5 and $10 \mathrm{mg}$, was lower than on days 1 and 3. Regarding the means observed found for room temperature and air relative humidity data (Table 2), results were contrary to those observed by McConaghy (1994), who reported that, when there is an increase in the room temperature, there is also an increase in HR, seeking loss of heat. Since this increase was not observed due the higher temperatures of the second day of test, it is supposed that the mares were adapted to the local climate and they probably presented smaller HR than on days 1 and 3 , because the relative humidity was lower on this day, what facilitated the heat exchange, reducing the thermal stress.

Table 1 - Heart rate (HR) mean of groups that received 0, 5 and $10 \mathrm{mg}$ of Cr, on days 1,2 and 3 of tests in phases 1 (before test) and 2 (after test)

\begin{tabular}{lccc}
\hline Days of test & \multicolumn{2}{c}{ Level of Cr (mg) } & CV (\%) \\
\cline { 2 - 4 } & & 5 & 10 \\
1 & $50.00 \pm 4.2 \mathrm{Ab}$ & Phase $1:$ HR before (bpm) & $57,25 \pm 10,6 \mathrm{Aa}$ \\
2 & $46.00 \pm 3.6 \mathrm{Ba}$ & $52.00 \pm 4.5 \mathrm{Aab}$ & $48,00 \pm 2,8 \mathrm{Ba}$ \\
3 & $48.75 \pm 3.7 \mathrm{Bb}$ & $47.25 \pm 4.6 \mathrm{Ba}$ & $55,75 \pm 6,2 \mathrm{Aa}$ \\
& & $51.75 \pm 5.3 \mathrm{Aab}$ & 7.26 \\
2 & $177,75 \pm 31,7 \mathrm{Aa}$ & Phase $2:$ HR after (bpm) & $157,25 \pm 58,5 \mathrm{Aab}$ \\
3 & $191,25 \pm 26,9 \mathrm{Aa}$ & $125,25 \pm 28,9 \mathrm{Bb}$ & $162,00 \pm 40,4 \mathrm{Aab}$ \\
\end{tabular}

Means follows by distinct small letter, within phase (row) or capital letter (column) are different $(\mathrm{P}<0.05)$ by $\mathrm{t}$-test. 
Table 2 - Room temperature $\left(\mathrm{T}^{\circ} \mathrm{C}\right)$ and air relative humidity ( $\mathrm{RH} \%)$ according to day of test at different hours

\begin{tabular}{|c|c|c|c|c|c|c|}
\hline \multirow[t]{3}{*}{ Day of test } & \multicolumn{6}{|c|}{ Day time (min) } \\
\hline & \multicolumn{2}{|c|}{7 a.m. } & \multicolumn{2}{|c|}{12 a.m. } & \multicolumn{2}{|c|}{6 p.m. } \\
\hline & $\mathrm{T}\left({ }^{\circ} \mathrm{C}\right)$ & RH(\%) & $\mathrm{T}\left({ }^{\circ} \mathrm{C}\right)$ & RH (\%) & $\mathrm{T}\left({ }^{\circ} \mathrm{C}\right)$ & RH (\%) \\
\hline 1 & 25.7 & 91 & 30 & 60 & 24.4 & 96 \\
\hline 2 & 25.8 & 91 & 32 & 58 & 26.7 & 91 \\
\hline 3 & 24.0 & 96 & 30 & 60 & 24.4 & 96 \\
\hline
\end{tabular}

It can be observed (Table 3) that, regardless the day of test, the groups that received 5 and $10 \mathrm{mg}$ of $\mathrm{Cr}$ showed lower average HR values during the times of evaluation $(\mathrm{P}<0.05)$. These results demonstrate that, regardless the day of test and the evaluation time, $\mathrm{Cr}$ showed positive influence in the heart performance on the suplemmented equines.

According to Gomes et al (2005), as a part of the glucose tolerance factor (GTF), Cr enhances the effects of insulin and increases the glucose tolerance, altering the energy metabolism. In equines submitted to exercise, Pagan et al (2000) observed that the animals supplemented with Cr presented lower blood glucose and insulin concentration, reduction of lactate with increase in the triglycerides levels during and immediately after exercise. This result probably occurred because of the larger lipids mobilization, as a consequence of the reduction in the insulin levels, what facilitated the use of other energy supply sources. This confirms the suspicion that equine suplemmented with $\mathrm{Cr}$

Table 3 - Heart rate (HR) of animals from the three experimental groups measured at different moments (immediately after the march test, and 5, 10, 15 and 20 minutes after the march test) in all three days of test, according to the levels of chrome

\begin{tabular}{lc}
\hline Level of chrome $(\mathrm{mg})$ & HR $(\mathrm{bpm})$ \\
\hline 0 & $105.69 \mathrm{~A}$ \\
5 & $91.83 \mathrm{~B}$ \\
10 & $89.92 \mathrm{~B}$ \\
\hline $\mathrm{CV}(\%)$ & 23.345 \\
\hline
\end{tabular}

Means followed by distinct capital letter are different by SMD $(\mathrm{P}<0.05)$. submitted to exercise has reduced fatigue, which influences positively in the heart performance of the animals.

Heart rate fast return was observed 5 minutes after the test, with stabilization of this return from 5 to 10 minutes and increase in the return speed 10 minutes after (Table 4; Figure 1).

The HR averages of the three days of test, at 5 minutes after the exercise, are close to the $110 \mathrm{bpm}$ average found by Pérez et al. (1997) also at 5 minutes after the test in horses from a Chilean rodeo. According to this author, the HR at this evaluation time after exercise is a reliable indicator of the horses fitness stage, because of the high repeatability. Fifteen minutes after exercise, in trained horses, means of $62 \mathrm{bpm}$ were observed. The results at 15 minutes after the exercise observed in the present work are above this value. However, these differences might have happened because marcha test is a different exercise than in rodeo contest.

According to Fernandes (1997), the HR return to normal levels occurs in a slower way than its elevation and in two different phases, being the first and more intense until 60 seconds after the end of the exercise. In this phase, the animal returns HR to submaximal levels that correspond to $60 \mathrm{bpm}$. The second phase, when the heart beats decreases to 60-70 bpm, to the animal basal level, is longer and has its duration period associated to the duration of the exercise, maintaining a relationship of 1:2 up to 1:1. The observed results (Table 4) show that, in the marcha test, until 20 minutes after the exercise, the animals did not present the values described by Fernandes (1997), who worked with thoroughbred racehorses. This result also confirms the presence of differences in the heart performance among animals that perform exercises from different modalities.

Gómez et al. (2004), studying the behavior of Holsteiner horses HR during and after exercise, observed that training produces physiological adaptation to individuals, translated into HR decreases after exercise. These authors measured HR at rest, immediately after the exercise and every 5 minutes until 15 minutes after the marcha test. The

Table 4 - Heart rate (HR) according to days of test measured before, after and during return ( 5, 10, 15 and 20 minutes after the march test)

\begin{tabular}{|c|c|c|c|c|c|c|}
\hline Day of test & Before & Immediately after & \multicolumn{4}{|c|}{ Time after the march test (min) } \\
\hline 1 & $53.08 \mathrm{Aa}$ & $153.42 \mathrm{Ab}$ & $106.08 \mathrm{ABC}$ & $99.25 \mathrm{Abc}$ & 82.83Ad & 75.33Ad \\
\hline 3 & $52.08 \mathrm{Aa}$ & $193.67 \mathrm{Bb}$ & $96.75 \mathrm{Bc}$ & $87.42 \mathrm{Bc}$ & 73.75Ad & 68.33Ad \\
\hline CV (\%) & 23.345 & & & & & \\
\hline
\end{tabular}

Means followed by distinct capital letter (column) or a small letter (row) are different $(\mathrm{P}<0.05)$ through SMD. 


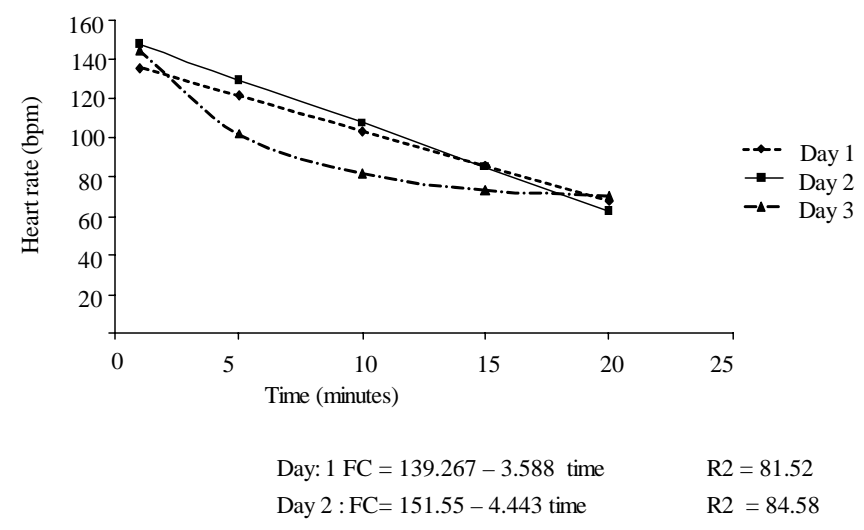

Figure 1 - Heart rate on time of evaluation for different days of test.

registered data showed that the HR return was faster at 5 , 10 and 15 minutes after exercise. These results are similar to those observed for the HR return behavior of animals from the three groups of this work (Table 4).

Table 4 also shows that the means HR values of the three groups, at 5 and 10 minutes after the marcha tests, in the three days, are higher than those suggested by Meirelles (1997). This author reported that when the animals are trained for endurance tests, they present HR below $72 \mathrm{bpm}$ at 5 and 10 minutes after the marcha test. It can be suspected that in the present work, a workload excess might have occurred, however, it should be considered that these differences can be related to differences in the intensity of the physical effort performed by the animals during endurance or marcha tests.

According to Clayton (1991), when the exercise ceases, equine HR remains between 60 and $100 \mathrm{bpm}$. Only at 20 minutes after exercise (Table 4), the animals showed HR close to the limits suggested by this author. On the third day, they finished the tests with higher HR than at the first and second day; however they returned quickly, possibly because of the cardio respiratory conditioning acquired after 30 days of training. Evans (1994) affirmed that the HR return is usually very fast in the first minutes after exercise, decreasing gradually to rest values and usually, the better conditioned is the animal, the more quickly the HR will return to the normal values. According to Silva et al. (2005), the HR return capacity after the exercise can be a great indicator to evaluate the animal adaptation to exercise and it can be inferred that, regardless the Cr supplementation, the training period accomplished was able to demonstrate good post exercise return indexes. Gómez et al. (2004) showed similar results observing that, after 30 days of training, Holsteiner horses showed faster HR return.
The HR return values observed (Table 4) are also in agreement with Bayly et al. (1983), who observed HR reduction in Standardbred horses along the period of submaximal aerobic training, even during the exercise and after it. These observations were also described by Muñoz et al. (1999), who found lower HR response to the exercise in trained and adapted horses to the exercise in relation to untrained animals.

The results observed are also in agreement with Clayton (1991) and Evans (1994), who reported that the HR return is usually very fast in the first minutes after exercise, decreasing gradually to rest values and usually, the better conditioned is the animal, the more quickly the HR will return to the normal values. For Silva et al. (2005), the HR return capacity after exercise can be a great indicator of the evaluation of the animal adaptation to exercise and to the room temperature. According to the authors, it can be inferred that the training period accomplished in the present work, for the three experimental groups, regardless the $\mathrm{Cr}$ supplementation, was enough so that the animals presented good pos exercise return indexes. These results must be considered in future researches, with Mangalarga Marchador horses in training for marcha tests, since the literature is scarce in works related with this modality of equestrian work.

The HR return values varied in relation to those mentioned in literature, which can be attributed to the great effort accomplished by the animals during the marcha test or to the different methodologies used in each experiment, since the present work was accomplished in field, with hot and humid atmosphere, simulating the reality of the equine preparation for marcha test used in practice. In experiments accomplished in treadmills, in exercise physiology laboratories, all conditions are controlled.

The analysis of the general average effect of the experimental groups, during the 50 minutes in the three days of tests (Figure 2) is important because, according to Evans (1994), the measures performed during the exercise describe the exercise intensity and the animal conditioning, besides the effects of the training and its lack.

The means HR values of all animals along the marcha test did not present great variations and Evans (1994) described that HR remains constant during submaximal exercise loads and that during prolonged exercises, it could vary, depending on the exercise intensity, environmental conditions and previous conditioning.

Analyzing the regression equation model for doses and days in function of times of evaluation during the 50 minutes of test, $\mathrm{HR}=136.106+3.4224$ time -0.0578 time $^{2}$, with $\mathrm{R}^{2}=81.33$ (Figure 2) it is observed, based on the 


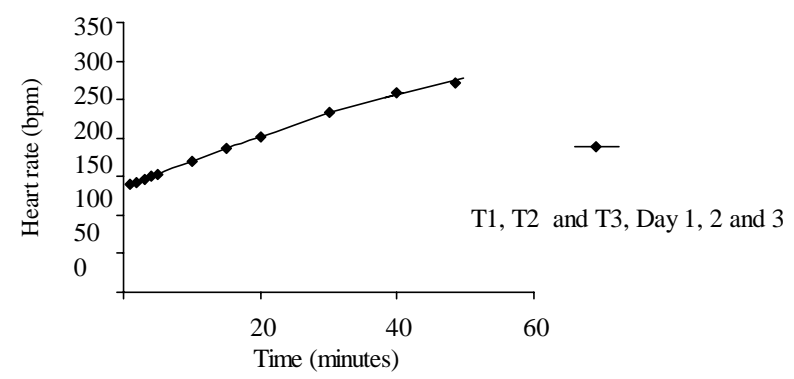

$\mathrm{FC}=136.106+3.4224$ time -0.0578 time $2 \quad \mathrm{R} 2=81,33$

Figure 2 - Heart rate (HR) for the level of Cr (0,5 and $10 \mathrm{mg} \mathrm{Cr}$ ) supplementation during the 50 minutes of test for 1 , 2 and 3 days of test.

prediction of the model, that at 29.6 minutes, the maximal HR for the three experimental groups was obtained, considering the three days of tests. This result demonstrates that, at this evaluation time, the mean value of $186.76 \mathrm{bpm}$ was recorded, which was the maximal HR presented among the animals of this study. This value is below the maximum heart rate interval (HRmax) suggested by Clayton (1991), which it is around 220 to $280 \mathrm{bpm}$, and it is also smaller than the HRmax mentioned by Evans (1994), from 220 to 260 bpm. It indicates that the marcha tests can be characterized as a submaximal intensity exercise.

According to Meirelles (1997), the HR oscillations in anaerobic exercises vary between 70 and $110 \mathrm{bpm}$. However, it is observed that the maximum HR value registered in the present study (186.76 bpm) was not in agreement with the interval suggested by this author. This result can be explained by the theory of the heart deviation, described by Powers \& Howley (2000). This physiologic phenomenon occurs when there are HR increase and reduction of the ejection volume, which is the amount of blood pumped by a heart beat during prolonged exercise, due to the influence of the increase in corporal temperature on dilatation of the cutaneous vessels and on dehydration (reduction of the plasmatic volume). The increase in cutaneous blood flow decreases the peripheral resistance and the reduction in the plasmatic volume acts together to reduce the venous return to the heart and, consequently, reduce the ejection volume. If a prolonged exercise is performed in hot and humid atmosphere, as in this study, the HR increases even more.

\section{Conclusions}

The addition of chrome in the diet of Mangalarga Marchador equines, during training for marcha tests, presented beneficial effect in the heart performance of the animals. The marcha tests can be characterized as a submaximal intensity exercise. Further researches should be conducted in order to define the training time and characterization to be accomplished with Mangalarga Marchador equines for competition in marcha tests.

\section{Literature Cited}

ASSOCIAÇÃO BRASILEIRA DOS CRIADORES DE CAVALO MANGALARGA Marchador - ABCCMM. XXIII Exposição Nacional do Cavalo Mangalarga Marchador. Belo Horizonte: 2004.

BALDISSERA, V. Fisiologia do exercício para eqüinos. Cadernos Técnicos da Escola de Veterinária, n.19, p.39-47, 1997.

BAYLY, W.M.; GABEL, A.A.; BARR, S.A. Cardiovascular effects of submaximal aerobic training on a treadmill in Standardbred horses, using a standardized exercise test. American Journal of Veterinary Research, v.44, n.4, p.544-553, 1983.

CLAYTON, H.M. Conditioning sport horses. Mason: Sport Horse Publications, 1991. 242p.

EVANS, D.L. The cardiovascular system: anatomy, physiology, and adaptations to exercise and traninig. In: HODGSON, D.R.; ROSE, R.J. (Eds.) The athletic horse. Philadelphia: W. B. Saunders Company, 1994. p.129-144.

FERNANDES, W.R. Avaliação clínica do sistema circulatório. Cadernos Técnicos da Escola de Veterinária, n.19, p.69-75, 1997.

GÓMEZ, C.; PETRON, P.; ANDAUR, M. et al. Medición postejercício de variables fisiológicas, hematológicas y bioquímicas em eqüinos de salto Holsteiner. Revista Científica, v.14, n.3, p.244-253, 2004.

GOMES, M.R.; ROGERO, M.M.; TIRAPEGUI, J. Considerações sobre cromo, insulina e exercício físico. Revista Brasileira de Medicina do Esporte, v.11, n.5, p.262-266, 2005.

GUERRA, P.; MEDEIROS, S.A.F. O agronegócio da eqüideocultura no Brasil. In: SIMPÓSIO MINEIRO DE EQÜIDEOCULTURA, 1., 2007, Viçosa, MG. Anais... Viçosa: [s.n.] 2007. p.188.

LEningher, A.L.; Nelson, L.; COX, M. Princípios de bioquímica. São Paulo: Sarvier, 1995. 839p.

McCONAGHY, F. Thermorregulation. In: HODGSON, D.R.: ROSE, R.J. (Eds.) The athletic horse. Philadelphia: W. B. Saunders Company, 1994. p.181-202.

MEIRELleS, J.S. O cavalo de enduro. Cadernos Técnicos da Escola de Veterinária, n.19, p.5-10, 1997.

MOWAT, D.N.; CHANG, X.; YANG, W.Z. Chelated chromium for stressed feeder calves. Canadian Journal of Animal Science, v.73, n.1, p.49-55, 1993.

MUÑOZ, A.J.; SANTITEBAN, R.; RUBIO, M.D. et al. Relationship between slope of the plasma lactate accumulation curve and working capacity in andalusian horses. Acta Veterinaria Brno, v.68, p.41-50, 1999.

NUTRIENT RESEARCH COUNCIL - NRC. Nutrient requirements of horses. 5.ed. Washington: National Academy of Science, 1989. 100p.

PAGAN, J.D.; JACKSON, S.G., DUREN, S.E. The effect of chromium supplementation on metabolic response to exercise in thoroughbred horses. In: EQUINE NUTRITION AND PHYSIOLOGY SOCIETY, 14., 1995, Ontario. Proceedings.. Ontario: 1995. p.96-101.

PEREZ, R.; GARCIA, M.; CABEZAS, I. et al. Actividad física y cambios cardiovasculares y bioquímicos del caballo chileno a la competencia de rodeo. Archivos de Medicina Veterinaria, v.29, n.2, p.221-234, 1997.

POWERS, S.K.; HOWLEY, E.T. Fisiologia do exercício: teoria e aplicação ao condicionamento e ao desempenho. São Paulo: Manole, 2000. 527p. 
REZENDE, A.S.C. Aditivos ou suplementos? Mangalarga Marchador. Revista Oficial da ABCСМM, v.18, n.59, p.44-48, 2006.

SILVA, L.A.C.; SANTOS, S.A.; SILVA, R.A.S. et al. Adaptação do cavalo pantaneiro ao estresse da lida diária de gado no pantanal, Brasil. Archivos de Zootecnia, v.54, n.206-207, p.509-513, 2005.
THOMAS, D.P.; FREGIN, G.F.; GERBER, N.H. et al. Effects of training on cardiorespiratory function in the horse. American Journal of Physiology, v.245, n.2, p.160-165, 1983.

WEIGLE, G.E.; LANGSETMO, I.; GALLAGHER, R.R. et al. Analysis of right ventricular function in the exercising horse: use of the Fourier transform. Equine Veterinary Journal, v.32, n.2, p.101-108, 2000. 